\title{
BAURAN PROMOSI TERHADAP PEMBELIAN KEMBALI PRODUK ELEKTRONIK PT. DIVA
}

\author{
Yulianti Dwi Astuti \\ Zakiyah Zahara \\ Banyamin Parubak \\ Program Studi S1 Manajemen, Fakultas Ekonomi, Universitas Tadulako \\ Email : astutiyulianti63@gmail.com;zakiyah66@gmail.com;beny0911@gmail.com
}

\begin{abstract}
This research will analyze the promotion mix on repurchasing electronic products at PT. Diva in Palu City, and will explain how much influence the promotional mix variables consist of advertising, personal sales and sales promotions on the repurchase of electronic products at PT. Diva in palu city. This research population is consumers of PT. Diva in palu city that buys electronic products that are unlimited in number. Sampling techniques from this study used purposive sampling, with a sample size of 60 respondents, researching data using a questionnaire which tested the validity and reliability. analysis method using multiple regression analysis. the results of research show that the promotional mix consisting of advertising, personal sales, and sales promotion has a significant effect on the repurchase of electronic products at PT. Diva in palu city.
\end{abstract}

Keywords: Advertising Personal Sales, Sales Promotion

\begin{abstract}
Abstrak
Penelitian ini akan menganalisis bauran promosi terhadap pembelian kembali produk elektronik pada PT. Diva di kota palu, dan akan menjelaskan seberapa besar pengaruh variabel bauran promosi yang terdiri dari periklanan, penjualan pribadi, dan promosi penjualan terhadap pembelian kembali produk elektronik PT. Diva di Kota Palu. Populasi penilitian ini adalah konsumen PT. Diva di Kota Palu yang membeli produk elektronik yang jumlahnya tidak terbatas. Teknik penarikan sampel dari penilitian ini menggunakan purposive sampling, dengan jumlah sampel sebanyak 60 responden. Penilitian data menggunkan kuesioner yang telah di uji validitas dan reabilitasnya. Metode analisis menggunkan Multiple Regression analisis. Hasil penelitian menunjukan bahwa bauran promosi yang terdiri dari periklanan, penjualan pribadi, dan promosi penjualan berpengaruh signifikan terhadap pembelian kembali produk elektronik PT. Diva Kota Palu.
\end{abstract}

Kata Kunci: Periklanan, Penjualan Pribadi, Promosi Penjualan

\section{PENDAHULUAN}

Pemasaran di dalam dunia usaha merupakan sesuatu yang sangat penting, sebab jika perusahaan tidak mampu menjual produknya kepada konsumen maka mengakibatkan kerugian, yang akhirnya akan mengakibatkan seluruh aktivitas yang ada dalam perusahaan akan mengalami kemacetan. Di antara toko-toko elektronik yang berkembang dikota palu, ada salah satu toko elektronik yang berdiri pada tahun 2013 yang mampu menarik penggannya untuk membeli kembali ke toko mereka yaitu PT. DIVA yang beralamat di jalan I gusti nguarai. Pesaing bisnis di bidang elektronik yang akan menjadikan PT. Diva harus mampu untuk mempertahankan dan meningkatkan konsumennya saat ini, Kegiatan promosi hasilnya tidak dapat diperoleh secara langsung atau kata lain efeknya tidak langsung kelihatan, tetapi dibutuhkan waktu sebelum dan sesudah terjadi penjualan. Besarnya biaya yang dibutuhkan oleh perusahaan untuk promosi relatif besar, maka diharapkan usaha ini dapat menarik konsumen untuk terus melakukan pembelian kembali. promosi merupakan suatu proses yang terus menerus harus dilakukan untuk tercapainya tujuan perusahaan. Sejalan dengan hal tersebut, upaya yang dilakukan dalam memasarkan suatu produk yakni dengan melakukan kegiatan promosi. (Kotler dan keller 2009) mengemukakan bahwa promosi meliputi, periklanan, promosi penjuala, acara dan pengalaman, hubungan masyarakat dan publisitas, pemasaran langsung, dan pemasaran interaktif, pemasaran dari mulut kemulut, dan penjualan pribadi. 
Demikian halnya dengan PT. Diva sebagai penyalur penjualan eletronik di Kota Palu yang berlokasi di jalan I Gusti Ngurah Rai, dari hasil observasi peneliti di lapangan, PT. Diva sudah sangat memperhatikan sistem pemasaran dan promosi penjualan secara efektif dalam penjualan produk elektronik. Akan tetapi, PT. Diva hanya menerapkan tiga dari tujuh bauran promosi yaitu: iklanan, dengan membagikan brosur kepada masyarakat umum agar masyarakat mengetahui tentang produk elektronik apa saja yang tersedia di PT. Diva. Selanjutnya, menerapkan penjualan pribadi, PT. Diva mempunyai tenaga marketing yang ditugaskan untuk turun langsung ke lapangan guna menawarkan langsung produk elektronik yang dijual oleh PT. Diva, dan yang terakhir adalah menerapkan promosi penjualan, dengan melakukan promosi seperti pemotongan harga, kupon, bonus dan lainya guna menarik konsumen untuk membeli produk elektronik di PT. Diva. Maka menerapkan tiga bauran pemasaran tersebut PT. Diva mengharapkan terwujudnya tujuan promosi perusahaan yaitu merebut pangsa pasar penjualan elektronik dari pesaing toko eletronik lainnya, karena salah satu faktor penentu keberhasilan suatu program pemasaran adalah promosi. Betapapun berkualitasnya suatu produk, bila konsumen belum pernah mendengarnya dan tidak yakin bahwa produk itu akan berguna bagi mereka, maka mereka tidak akan pernah membelinya.

PT. Diva adalah perusahaan elektronik yang merupakan anak persuhaan dari Colombus Group yang berdiri sejak tahun 2013, PT. Diva beralamat di Jl. I. Gusti Ngurah Rai Kota Palu, Sulawesi tengah. Perusahaan ini memiliki kurang lebih 50 karyawan yang terdiri dari 1 orang General manager, 4 orang Accounting, 11 orang Account Receivable, 1 orang Adm.analisis, 1 orang Adm. Marketing, 3 orang Supervisor, 6 orang Pramuniaga, dan 23 orang tenaga marketing. PT. Diva elektronik berkomitmen memberikan pelayanan terbaik bagi konsumen, dengan menyediakan beragam prdoduk berkualitas. berbagai macam produk yang dijual antara lain : Kulkas, Tv, Ac, Mesin cuci dan Home theater. Promosi yang dilakukan oleh manajemen PT. Diva Palu adalah periklanan menggunakan promosi melalui media cetak dengan membagikan brosur, penjualan pribadi dengan promosi langsung tenaga marketing kepada konsumen, dan promosi Penjualan melalui pameran.

Berdasarkan uraian di atas maka penulis tertarik untuk melakukan penilitian dengan judul analisis bauran promosi terhadap pembelian kemali produk elektronik pada PT. Diva di kota palu, dengan alasan untuk pemberian judul dalam karya tulis ini, untuk menambah pengalaman dan pengetahuan, serta agar pembaca tertarik untuk membaca dan memahami karya tulis ini Bedasarakan dengan uraian di atas juga. maka penulis merumuskan masalah sebagai berikut: (1) Apakah bauran promosi yang terdiri dari periklanan, penjualan pribadi, dan promosi penjualan secara simultan berpengaruh signifikan terhadap pembelian kembali produk elektronik PT. Diva di Kota Palu? (2) Apakah variabel periklanan secara parsial berpengaruh signifikan terhadap pembelian kembali produk elektronik PT. Diva di Kota Palu?

(3) Apakah variabel penjualan pribadi secara parsial berpengaruh signifikan terhadap pembelian kembali produk elektronik PT. Diva di Kota Palu? (4) Apakah variabel promosi penjualan secara parsial berpengaruh signifikan terhadap pembelian kembali produk elektronik PT. Diva di Kota Palu?

\section{KAJIAN LITERATUR DAN PENGEMBANGAN HIPOTESIS}

Dalam menjalankan kegiatan perusahaan harus bisa melakukan aktivitas pemasaran sehingga perusahaan dapat menawarkan produk yang di hasilkan kepada konsumen dan mencapai tujuan dengan strategi pemasaran yang tepat. Bauran pemasaran (Marketing mix) merupakan konsep kunci teori dalam pemasaran modern. Marketing mix di gunakan karena adanya pesaing dari perusahaan lain. Selain itu, setiap perusahaan dituntut untuk selalu menerapkan konsep pengembangan strategi pemasaran yang berkaitan dengan masalah menetapkan pilihan untuk menawarkan bagi segmen pasar tertentu. Pilihan bentuk penawaran ini dapat terpecahkan dengan penerapan strategi pemasaran yang disebut Marketing Mix. Promosi sangat diperlukan sekali untuk meningkatkan penjualan selain dari 
harga produk. Setiap orang tidak akan mengetahui tentang produk yang dijual dipasar tanpa adanya promosi.

Konsumen dapat mengetahui tentang kekurangan dan kelebihan produk serta bentuk maupun kualitasnya dengan adanya promosi. Jadi, promosi merupakan salah satu variabel dari marketing mix yang perlu dilaksanakan oleh suatu perusahaan dalam rangka meningkatkan volume penjualan barang atau jasa kepada konsumen. Promosi merupakan salah satu variabel dari bauran pemasaran (Marketing mix) yang bertujuan untuk mengomunikasikan produk dengan calon pembeli potensial melalui berbagai unsur yang terdapat dalam program promosi. Program promosi merupakan saluran komunikasi utama terhadap calon pembeli.

Promosi menurut Kotler dan Keller $(2009 ; 174)$ agar peusahaan mencapai tujuan dari komunikasi, perusahaan dapat menggunakan alat bantu yang terdiri dari delapan model komunikasi, yaitu: (1) Periklanan adalah semua bentuk terbayar dari presentasi nonpersonal dan promosi ide, barang, atau jasa melalui sponsor yg jelas, (2) Promosi penjualan berbagai insentif jangka pendek yang mendorong percobaan atau pembelian produk atau jasa, (3) Acara dan pengalaman yaitu kegiatan dan program yang disponsori perusahaan yang dirancang untuk menciptakan interaksi harian atau interaksi yang berhubungan dengan merek tertentu, (4) Hubungan masyarakat dan Publisitas beragam program yang dirancang untuk mempromosikan atau melindungi citra perusahaan atau produk individunya, (5) Pemasaran langsung dan pemasaran interaktif merupakan kegiatan dan program yang dirancang untuk melibatkan pelanggn atau prospek dan secara langsung atau tidak langsung meningkatkan kesadaran, memperbaiki citra, atau menciptakan penjualan produk atua jasa, (6) Pemasaran dari mulut kemulut komunikasi lisan, tertulis, dan elektronik antar masyarakat yang berhubungan dengan keunggulan atau pengalaman membeli atau menggunkan produk atau jasa (7) Penjualan personal adalah interaksi tatap muka dengan satu atau lebih pembeli prospektif untuk tujun melakukan presentsi, menjawab pertanyan, dan mengadakan pesanan.

Orang melakukan promosi untuk mencapai suatu tujuan tertentu, adapun tujuan promosi berdasarkan rangkuman dari berbagai sumber adalah: (1) Menyebarkanluaskan informasi suatu produk kepada calon konsumen yang potensial, (2) Mendapatkan konsumen baru dan untuk menjaga loyalitas konsumen tersebut, (3) Menaikkan penjualan serta laba/keuntungan, (4) Membedakan dan mengunggulkan produknya dibandingkan dengan produk competitor, (5) Branding atau membentuk citra produk di mata konsumen sesuai dengan yang diinginkan, (6) Merubah tingkah laku dan pendapat konsumen tentang suatu produk

Menurut Kotler et.al (2012:422) mengatakan ada 4 metode umum yang dipakai untuk menetapkan biaya promosi yaitu: (1) Metode sesuai kemampuan (Affordable Method), perusahaan menetapkan anggaran promosi sebatas yang perusahaan perkirakan dapat ditanggung oleh perusahaan. (2) Metode persentase penjualan (Percentage of Sales Method), perusahaan menetapkan biaya promosi sebesar persentas tertentu dari penjualan saat ini atau yang diramalkan, (3) Metode menyamai mesaing (Competitive Parity Method), perusahaan menyamakan biaya promosi dengan biaya perusahaan pesaing, (4) Metode tujuan dan tugas (Objective and Task Method), perusahaan menetapkan biaya promosi berdasarkan apa yang ingin dicapai dengan promosi.

Kotler dan Keller (2009:213) mengatakan bahwa, "perilaku konsumen merupakan studi tentang cara individu, kelompok, dan organisasi menyeleksi, membeli, menggunakan, dan mendisposisikan barang, jasa, gagasan, atau pengalaman untuk memuaskan kebutuhan dan keinginan mereka.”

Menurut Schiffman dan Kanuk (2010:23), perilaku konsumen (consumer behavior) dapat didefinisikan sebagai perilaku dimana konsumen menunjukkan dalam hal mencari (searching for), membeli (purchasing), menggunakan (using), mengevaluasi (evaluating), dan membuang produk dan jasa yang diharapkan akan memuaskan kebutuhan (disposing of products and services that they will satisfy their needs). 
Swastha dan Irwan (2009:331) menyatakan bahwa pembelian kembali merupakan suatu sikap perilaku konsumen yang hanya membeli sebuah produk atau jasa secara berulang-ulang tanpa menyertakan aspek kesukaan di dalamnya, sehingga tercipta loyalitas konsumen yang nerupakan suatu komitmen terdapat suatu merek atau produk tertentu, toko, pemasok atau perusahaan berdasarkan sikap positif yang tercermin dalam pembelian ulang yang konsisten.

\section{METODE PENELITIAN}

Jenis penilitian yang dilakukan dalam dalam penilitian ini adalah kuasalitas, jenis data: (1) data kuantitatif dan (2) data kualitatif, sumber data: (1) data primer dan (2) data Skunder, Populasi dalam penilitian ini adalah konsumen PT. DIVA di kota palu yang membeli lebih dari 1 kali. Yang berjumlah 60 responden. Teknik penarikansampel adalah bagian dari jumlah dan karakteristik yang dimiliki oleh populasi tersebut (Sugiyono, 2014:149). Teknik penarikan sampel yang akan digunakan dalam penelitian ini yaitu purposive sampling.Purposive sampling adalah cara pengambilan sampel berdasarkan karakteristik tertentu seperti: (1) Pengunjung yang sudah pernah membeli produk elektronik di PT. Diva (2) Berdomisili di Kota Palu, Sigi dan Donggala (3) Berusia 17 tahun ke atas.

Instrumen Menurut Umar (2010:254) bahwa dalam melakukan uji coba kuesioner jumlah responden yang dibutuhkan minimal 30 orang. Jumlah minimal 30 orang ini, distribusi skor (nilai) akan lebih mendekati kurva normal. Uji validitas dan reliabilitas dilakukan dengan menggunakan bantuan aplikasi komputer (software) program IBM SPSS Statistics Version 16. Menurut Sugiyono (2014:188) syarat minimum untuk dianggap memenuhi syarat adalah $\mathrm{r}=0,3$. Jadi, korelasi antara butir dengan skor total kurang dari 0,3 maka butir dalam instrumen tersebut dinyatakan tidak valid. Sebaliknya jika skor total positif dan lebih besar dari 0,3 (r>0,3) maka instrumen tersebut valid. Menurut Azwar (2003: 60) reliabilitas alat ukur menunjukkan sejauh mana hasil usaha pengukuran dapat dipercaya. Hasil pengukuran dapat dipercaya apabila beberapa kali pelaksanaan pengukuran terhadap sekelompok subyek yang sama memperoleh hasil yang sama pula. Malhotra dalam Solimun (2002: 81) mengatakan bahwa suatu instrument atau seluruh indikator dianggap sudah cukup reliable apabila memiliki alpha cronbach lebih besar $0,6(\alpha>0,6)$.

\section{Uji Asumsi klasik}

\section{Uji Normalitas}

Normalitas bertujuan menguji apakah dalam sebuah model regresi, variabel dependen (terikat), variabel independen (bebas) atau keduanya mempunyai distribusi data normal atau mendekati normal. Deteksi normalitas dilakukan dengan melihat penyebaran dan (titik) pada sumbu diagnosis dari grafik. Dasar pengambilan keputusannya adalah:

1. Jika data tersebut disekitar garis diagonal dan mengikuti arah gratis diagonal, maka model regresi memenuhi asumsi normalitas.

2. Jika data menyebar jauh dari garis diagonal dan/tidak mengikuti arah garis diagonal, maka model regresi tidak memenuhi asumsi normalitas.

\section{Uji Multikolinearitas}

Uji multikolinearitas bertujuan untuk menguji apakah model regresi ditemukan adanya korelasi antarvariabel bebas (independen). Model regresi yang baik seharusnya tidak terjadi korelasi di antara variabel independen (Ghozali, 2006: 91). Jika terjadi korelasi kuat, terdapat masalah multikolinearitas yang harus diatasi. Menurut Ghozali (2006: 91), untuk mendeteksi ada atau tidaknya multikolineritas di dalam model regresi dilakukan dengan cara melihat nilai Tolerance dan lawannya Variance Inflation Factor (VIF). Kedua ukuran ini menunjukan setiap variabel independen manakah yang dijelaskan oleh variabel independen lainya. Tolerance mengukur variabilitas variabel independen terpilih yang tidak dijelaskan oleh variabel independen lainnya. Nilai tolerance yang rendah sama dengan nilai VIF tinggi (karena VIF $=1$ /Tolerance, dimana Tolerance $=1-\mathrm{R} 2$ ). Nilai cutoff yang umum dipakai untuk menunjukan adanya multikolinearitas adalah nilai tolerance $\leq 0,10$ atau sama dengan nilai $\mathrm{VIF} \geq 10$.

\section{Uji Heteroskedastisitas}


Uji heteroskedastisitas bertujuan untuk menguji apakah dalam model regresi terjadi ketidaksamaan variance dari residual satu pengamatan ke pengamatan yang lain. Jika variance dari residual satu pengamatan ke pengamatan lain tetap, maka disebut homoskedastisitas dan jika berbeda disebut heteroskedastisitas. Model regresi yang baik adalah variabel homoskedastisitas atau tidak terjadi heteroskedastisitas (Ghozali, 2006: 105).

Menurut Ghozali (2006: 105), untuk mendeteksi ada atau tidaknya heteroskedastisitas adalah dengan cara melihat grafik plot antara nilai prediksi variabel terikat (dependen) yaitu ZPRED denga residualnya SRESID. Deteksi ada tidaknya heteroskedastisitas dapat dilakukan dengan melihat ada tidaknya pola tertentu pada grafik scatterplot antara SRESID dan ZPRED dimana sumbu Y adalah Y yang telah dipredisi, dan sumbu $\mathrm{X}$ adalah residual ( $\mathrm{Y}$ prediksi - $\mathrm{Y}$ sesungguhnya) yang telah distudentized. Dasar analisisnya adalah:

1) Jika ada pola tertentu, seperti titik-titik yang ada membentuk pola tertentu yang teratur (bergelombang, melebur kemudian menyempit), maka mengindikasikan telah terjadi heteroskedastisitas, maka perlu dilakukan transformasi data.

2) Jika tidak ada pola yang jelas, serta titik-titik menyebar di atas dan di bawah angka 0 (nol) pada sumbu Y, maka tidak terjadi heteroskedastisitas.

\section{Analisis Regresi Berganda}

Untuk mengukur dan menganalisis besarnya pengaruh citra perusahaan dan kualitas pelayanan terhadap pembelian kembali produk elektronik di PT. Diva Kota Palu, menggunakan alat analisis statistic parametric regresi linear berganda (Multiple Regression Analisis).

Menurut pendapat yang dijelaskan oleh Sugiyono (2014:277) bahwa model umum bentuk persamaan alat analisis statistic parametric regresi linear berganda dapat digambarkan sebagai berikut:

$$
\mathbf{Y}=\mathbf{a}+\mathbf{b}_{1} \mathbf{X}_{1}+\mathbf{b}_{2} \mathbf{X}_{2}+\mathrm{b}_{3} X_{3}+e
$$

$$
\begin{array}{ll}
\mathrm{Y} & \multicolumn{2}{l}{\text { Dimana }:} \\
& =\text { Pembelian Kembali } \\
\mathrm{X}_{1} & =\text { Periklanan } \\
\mathrm{X}_{2} & =\text { Penjualan pribadi } \\
\mathrm{X}_{3} & =\text { Promosi penjualan } \\
\mathrm{a} & =\text { Konstanta } \\
\mathrm{b}_{1-} \mathrm{b}_{2} & =\text { Koefisien Regresi }
\end{array}
$$

\section{Pengujian Hipotesis Pertama (Uji Simultan/ Uji F)}

Uji ini digunakan untuk mengetahui seluruh variabel independen secara simultan mempunyai pengaruh yang signifikan terhadap variabel. Dimana F (hitung)> F (tabel), maka H1 diterima atau secara bersama-sama variabel bebas dapat menerangkan variabel terikatnya secara serentak. Sebaliknya apabila $\mathrm{F}$ (hitung) < F(tabel), maka HO diterima atau secara bersama-sama variabel bebas tidak memiliki pengaruh terhadap variabel terikat. Untuk mengetahui signifikan atau tidak pengaruh secara bersama-sama variabel bebas terhadap variabel terikat maka digunakan probability sebesar 5\% $(\alpha=0,05)$. Yaitu dengan ketentuan sebagi berikut :

1. Jika sig $>\alpha \dot{\alpha}(0,05)$, maka hipotesis ditolak.

2. Jika sig $<\dot{\alpha}(0,05)$, maka hipotesis diterima.

\section{Pengujian Hipotesis Kedua ( Uji Parsiial / Uji t)}

Menurut (Purwanto 2006), untuk mengetahui apakah suatu variabel secara parsial berpengaruh nyata atau tidak, digunakan uji $\mathrm{t}$ atau $t$-student. Untuk melakukan uji $\mathrm{t}$ dapat dilakukan dengan beberapa cara, diantaranya menentukan daerah kritis. Daerah kritis ditentukan oleh nilai t (tabel) dengan derajat kebebasan yaitu $n-k$, dengan taraf $\alpha$.pengujian ini untuk mengetahui pengaruh masing- 
masing variabel independen secara parsial berpengaruh signifikan terhadap variabel dependen di lakukan dengan pengujian Uji $\mathrm{t}$, dimana derajat signifikan yang digunakan adalah $\alpha=0,05$ dengan bentuk pengujian sebagai berikut:

1. Jika nilai signifikan (sig. $\mathrm{t}$ ) $\leq \alpha=0,05$, artinya masing-masing variabel independen secara parsial berpengaruh signifikan terhadap pembelian kembali produk elektronik di PT. Diva Kota Palu. Dengan demikian dapat dinyatakan bahwa hipotesis yang diajukan dalam penelitian ini masingmasing diterima secara parsial.

2. Jika nilai signifikan (sig. $\mathrm{t}$ ) $\geq \alpha=0,05$, hal ini artinya masing-masing variabel independen secara parsial berpengaruh tidak signifikan terhadap pembelian kembali produk elektronik di PT. Diva Kota Palu. Dengan demikian dapat dinyatakan bahwa hipotesis yang diajukan dalam penelitian ini masing-masing ini ditolak secara parsial.

\section{Koefisien Determinasi (R2)}

Koefisien determinasi (R2) pada intinya mengukur seberapa jauh kemampuan model dalam menerangkan variasi variabel independen. Nilai koefisien determinasi adalah antara nol dan satu. Nilai R2 yang kecil berarti kemampuan variabel-variabel independen dalam menjelaskan variasi variabel dependen sangat terbatas. Nilai yang mendekati satu berarti variabel-variabel independen memberikan hampir semua informasi yang dibutuhkan untuk memprediksi variasi variabel dependen.

\section{HASIL DAN PEMBAHASAN}

\section{Uji Regresi Linear Berganda}

Penelitian ini bertujuan untuk mengetahui besarnya pengaruh secara simultan dan persial antara promosi penjualan terhadap pembelian kembali produk elektronik pada pt diva di kota palu. Untuk menguji kebenaran hipotesis yang diajukan dalam penilitian ini, menunggunakan metode analisis regresi linier berganda.Sementara itu untuk menguji permasalahan dan hipotesis pertama yang telah dirumuskan digunakan uji $\mathrm{F}$, sedangkan menguji permasalahan dan hipotesis kedua digunakan uji t, dengan menggunakan bantuan program komputer SPSS for Windows versi 16.0. Ringkasan hasil pengolahan data dengan menggunakan program SPSS tersebut adalah sebagai berikut:

Tabel 6 Hasil Uji Regresi Berganda

\begin{tabular}{|c|c|c|c|c|c|}
\hline \multicolumn{6}{|c|}{ Dependen Variabel Y = Pembelian Kembali } \\
\hline \multirow[t]{2}{*}{ Variabel Independen } & \multicolumn{2}{|c|}{$\begin{array}{l}\text { Unstandardized } \\
\text { Coefficients }\end{array}$} & \multirow{2}{*}{$\begin{array}{c}\begin{array}{c}\text { Standardized } \\
\text { Coefficients }\end{array} \\
\text { Beta }\end{array}$} & \multirow[t]{2}{*}{$\mathbf{T}$} & \multirow[t]{2}{*}{ Sig } \\
\hline & $\mathbf{B}$ & $\begin{array}{c}\text { Standar } \\
\text { Error }\end{array}$ & & & \\
\hline $\mathrm{C}=$ Constanta & .541 & .235 & & 2.303 & .025 \\
\hline Periklanan $\left(\mathrm{X}_{1}\right)$ & .648 & .049 & .763 & 13.204 & .000 \\
\hline PenjualanPribadi $\left(\mathrm{X}_{2}\right)$ & .380 & .049 & 397 & 7.757 & .000 \\
\hline PromosiPenjualan $\left(\mathrm{X}_{3}\right)$ & .135 & .048 & .150 & 2.799 & .007 \\
\hline $\begin{array}{l}\text { Multiple R }=.940 \\
\text { Adjusted R Square }\left(\mathrm{R}^{2}\right)=\end{array}$ & $8 \mathrm{~F}$ & $\begin{array}{r}\mathrm{Si} \\
=142.03\end{array}$ & $=.000$ & & \\
\hline
\end{tabular}

Sumber: Data Primer diolah 2018

Hasil table tersebut apabila ditulis dalam bentuk dari persamaan regresinya adalah sebagai berikut :

$$
Y=0.541+0,648 X 1+0,380 X 2+0,135 X 3
$$

Adapun penjelasan bentuk persamaan tersebut, adalah sebagai berikut:

1. Nilai Konstanta $Y$ (Pembelian Kembali) sebesar 0.541. Artinya, jika nilai variabel periklanan $\left(\mathrm{X}_{1}\right)$, penjualan pribadi $\left(\mathrm{X}_{2}\right)$, danpromosi penjualan $\left(\mathrm{X}_{3}\right)$ bernilai 0 , maka variabel dependen pembelian kembali (Y) sebesar 0.541. Setiap ada kenaikan pada variabel independen sebesar satu satuan maka akan meningkatkan variabel dependen yaitu pembelian kembali. 
2. Koefisien regresi variabel periklanan $\left(\mathrm{X}_{1}\right)$ sebesar 0,648. Artinya, jika ada kenaikan pada variabel periklanan $\left(\mathrm{X}_{1}\right)$ maka variabel pembelian kembaliakan meningkat pula. Variable periklanan menjadi variable yang paling dominan .

3. Koefisien regresi variabel penjualan pribadi $\left(\mathrm{X}_{2}\right)$ sebesar 0,380 . Artinya, jika ada kenaikan pada variabel penjualan pribadi $\left(\mathrm{X}_{2}\right)$ jika pembelian pribadi meningkat positif maka pembelian kembali akan meningkat juga .

4. Koefisien regresi variabel promosi penjualan $\left(X_{3}\right)$ sebesar 0,135. Artinya, jika ada kenaikan pada variabel promosi penjualan $\left(\mathrm{X}_{3}\right)$ maka variabel pembelian kembali akan meningkat pula.

5. Koefisien korelasi (Multiple R) sebesar 0,940 ini menunjukan bahwa hubungan antara variabel independen dengan variabel dependen sebesar $88,4 \%$. Melihat angka tersebut maka dapat disimpulkan hubungan yang signifikan antara variabel independendengan variabel dependen nilai $\left(\mathrm{R}^{2}\right)$ atau kofesien determinasi sebesar 0,884 nilai tersebut menunjukan besarnya bauran promosi secara keseluruhan terhadap pembelian kembali.

\section{Pengujian Hipotesis Pertama (Uji F)}

Menurut Jonathan dan Sarwono (2006: 74) kriteria pengujian dilakukan dengan menggunakan angka signifikansi atau Sig, untuk keperluan di atas diperlukan hipotesis dan dengan kriteria sebagai berikut, jika angka signifikansi penelitian $<0,05$; maka hipotesis diterima dan jika angka signifikansi penelitian > 0,05; maka hipotesis ditolak. Berdasarkan data yang diperoleh angka signifikansi $\mathrm{F}$ sebesar 0,000. Angka 0,000 < 0,05 oleh karena itu, hipotesis diterima. Artinya adanya pengaruh signifikan variabel bauran promosi yang terdiri dari periklanan (X1), penjualan pribadi (X2), dan promosi penjualan (X3) terhadap pembelian kembali pada PT. Diva di Kota Palu.

\section{Pengujian Hipotesis kedua (Hasil Uji t)}

Uji t dimaksudkan untuk mengetahui seberapa besar pengaruhvariabel independen bauran promosi (X) secara parsial dalam menerangkan variabel dependen (pembelian kembali). Langkah-langkah dalam menguji hipotesis adalah sebagai berikut: (1) Variabel Periklanan $\left(\mathrm{X}_{1}\right)$ Hasil pengujian dengan SPSS diperoleh angka signifikansi sebesar 0,000. Angka 0,000<0,05 oleh karena itu, hipotesis diterima. Hal ini berarti variabel $\mathrm{X}_{1}$ (periklanan) berpengaruh signifikan terhadap variabel $\mathrm{Y}$ (pembelian kembali) : (2) Variabel Penjualan Pribadi $\left(\mathrm{X}_{2}\right)$ hasil pengujian dengan SPSS angka signifikansi sebesar 0,000. Angka 0,000 $<0,05$ oleh karena itu, hipotesis diterima. Hal ini berarti variabel $\mathrm{X}_{2}$ (penjualan pribadi) berpengaruh signifikan terhadap variabel $\mathrm{Y}$ (pembelian kembali) : (3) Variabel Promosi Penjualan $\left(\mathrm{X}_{3}\right)$ hasil pengujian dengan SPSS angka signifikansi sebesar 0,009. Angka $0,007<0,05$ oleh karena itu, hipotesis diterima. Hal ini berarti variabel $\mathrm{X}_{3}$ (promosi penjualan) berpengaruh signifikan terhadap variabel Y (pembelian kembali).

\section{Pembahasan}

Menurut (Kotler dan Keller 2009) ada tujuh model bauran komunikasi pemasaran yaitu; iklan, promosi penjualan, acara dan pengalaman, hubungan masyarakat dan publisitas, pemasaran langsung, pemasaran dari mulut kemulut dan penjualan personal. Tetapi PT. Diva hanya menerapkan 3 model tersebut yaitu periklan, penjualan pribadi dan promosi penjualan. Yang dimana variabel periklanan merupakan variabel yang paling dominan.

\section{Variabel Periklanan (X1)}

Brosur merupakan media pemasaran yang efektif untuk melakukan promosi, karena dalam brosur tersebut terdapat gambar barang yang tersedia disuatu perusahaan sehigga konsumen dapat melihat contoh barang yang akan dibelinya, dari cara melakukan promosi dengan menggunakan brosur dapat menarik perhatian konsumen untuk melakukan pembelian kembali.Begitupun halnya dengan PT. Diva kota, juga menggunakan brosur untuk melakukan promosi pemasaran agar dapat menarik konsumennya untuk melakukan pembelian kembali. Perusahaan ini melakukan strategi pemasaran dengan menggunakan sekaligus menyebarkan brosur kepada seluruh masyarakat yang dianggap berpeluang untuk menjadi konsumen di PT. Diva. Brosur yang di sebarkan adalah brosur yang sudah 
didesain sedemikian rupa agar tampilannya menarik hati calon konsumen. Bentuk pesan tentang suatu produk akan mendekatkan dengan perilaku pembelian. Penelitian ini didukung oleh penelitian yang dilakukan oleh Febryan Sandi (2014) yang mengungkapkan bahwa segala bentuk pesan tentang suatu produk atau jasa yang disampaikan lewat suatu media dan ditunjukan kepada sebagian atau seluruh masyarakat.

\section{Variabel Penjualan Pribadi (X2)}

Presentasi penjualan yang dilakukan oleh tenaga marketing PT. Diva di Kota paludapat mempengaruhi perilaku konsumen dalam pembelian kembali terhadap produk-produk elektronik yang ditawarkan oleh PT. Diva di Kota Palu.Penjualan Pribadi merupakan interaksi langsung dengan satu calon pembeli atau lebih guna melakukan presentasi, menjawab pertanyaan, dan menerima pesanan. Hal ini menunjukan bahwa presentase yang dilakukan oleh tenaga marketing PT. Diva Palu membuat konsumen tertarik untuk terus mendengarkan penjelasan-penjelasan yang dipaparkan, ini berarti akan mendekatkan konsumen pada perilaku pembelian. Tenaga marketing PT. Diva melakukan presentase ke lapangan langsung seperti door to door dengan tujuan memperkenalkan berbagai macam produk Elektronik yang dijual oleh PT. Diva. cara ini tenaga marketing langsung bisa merasakan feedback dari presentase yang mereka lakukan, apakah konsumen tertarik untuk melakukan pembelian kembali atau konsumen tidak tertarik sama sekali. Penelitian ini didukung oleh hasil penelitian yang dilakukan oleh (Fadhli Nurfakhrusy:2017) yang menjelaskan bahwap penjualan personal berpengaruh positif dan signifikan terhadapkeputusan pembelian motor Yamaha Fino di PT Lautan Teduh SentralYamaha Bandar Lampung.

\section{Variabel Promosi Penjualan (X3)}

PT. Diva palu memberikan bonus barang secara cuma-cuma kepada konsumen agar konsumen dapat melihat contoh barang yang akan dibelinya. Hal ini dapat menarik konsumen untuk melakukan pembelian kembali dan memberikan pengalaman secara langsung kepada konsumen. Selain itu, pengetahuan konsumen terhadap produk PT. Diva juga akan semakin bertambah. Ketika sudah merasakan atau menggunakan secara langsung produk yang diberikan, tentu konsumen akan semakin aware terhadap produk yang ditawarkan.Penelitian ini juga didukung pendapat dari Saladin dan Djasmin (2012:136) adalah "Suatu perencanaan untuk membantu atau melengkapi koordinasi periklanan dan penjualan pribadi". Menurut pendapat diatas dapat disimpulkan bahwa promosi penjualan adalah daya upaya mempengaruhi keputusan pembelian dimana perusahaan dapat memilih atau kiat promosi mana yang cocok dipakai untuk mendorong terjadinya pembelian produk atau jasa tertentu secara cepat.

\section{KESIMPULAN DAN SARAN}

\section{Kesimpulan}

Berdasarkan hasil penelitian dan pembahasan, maka dapat ditarik kesimpulan sebagai berikut:

1. Bauran promosi yang terdiri dari periklanan, penjualan pribadi, dan promosi penjualan secara simultan berpengaruh signifikan terhadap pembelian kembali produk elektronik PT. Diva di Kota Palu.

2. Variabel periklanan secara parsial berpengaruh signifikan terhadap pembelian kembali produk elektronik PT. Diva di Kota Palu.

3. Variabel penjualan pribadi secara parsial berpengaruh signifikan terhadap pembelian kembali produk elektronik PT. Diva di Kota Palu.

4. Variabel promosi penjualan secara parsial berpengaruh signifikan terhadap pembelian kembali produk elektronik PT. Diva di Kota Palu.

\section{Saran}

Berdasarkan hasil penelitian, pembahasan dan kesimpulan yang diperoleh, maka saran yang dapat diberikan sebagai berikut : 
1. Hasil tanggapan responden pada variabel periklanan mengenai indikator menggunakan papan iklan merupakan indikator dengan nilai mean terendah. Disarankan kepada PT. Diva Palu sebaiknya lebih mengembangkan media periklanannya, dengan menggunakan media online, seperti melakukan promosi melalui media online buka lapak dan took pedia.

2. Hasil tanggapan responden pada variabel promosi penjualan mengenai indikatormelakukan pameran merupakan indikator dengan nilai mean terendah. Disarankan kepada pihak PT. Diva Kota Palu untuk meminimalisir melakukan promosi produk-produknya di pameran-pameran, karena kurangnya feedback bagi perusahaan.

3. Hasil tanggapan responden pada variabel pembelian kembali mengenai indikator melakukan pembelian ulangmerupakan indikator dengan nilai mean terendah. Agar supaya minat konsumen untuk membeli kembali produk elektronik di PT. Diva Kota Palu besar, maka diperlukan perhatian khusus dari pihak manajemen dalam menyusun strategi pemasaran yang efektik untuk hal ini.

4. Bagi peneliti selanjutnya yang ingin meneliti atau melanjutkan penelitian ini, disarankan untuk meneruskan atau mengembangkan penelitian ini dengan mencari faktor lain yang dapat mempengaruhi pembelian kembali seperti faktor citra perusahaan, store atmosphere dan kualitas pelayanan.

\section{REFERENSI}

Azwar. S., (2003). Metode Penelitian, Pustaka Pelajar, Yogyakarta.

Engel, J. F., Blackwell, R. D \& Miniard, P . W 2001, edisi keenam. Binarupa Aksara. Jakarta

Johan, Sarwono, 2006, Metode Penilitian Kuantitatif dan Kumulatif, edisi, Pertama, Graha Ilmu Yogyakarta

Kotler, P., Keller, K. L. ( 2009 ). Manajemen pemasaran.edisi 13. Jakarta: Erlangga

Kotller, Philip and Eary Amstrong. 2012 Prinsip-Prinsip Pemasaran.Edisi 13.Jilid 1. Jakarta:Erlangga

Sandy, Febryan, 2014. Pengaruh Bauran Promosi terhadap Keputusan Pembelian (Jurnal). Diakses di administrasibisnis.studentjournal.ub.a.c.id

Saladin, Djasmin, 2012 Manajemen Pemasaran, Bentuk-Bentuk Penjualan Personal Edisi 6. Banadung Alfabeta

Schiffman, Leon G. dan Laslie Lazar Kanuk. (2010) Consumer Behavior Tenth Edition, Pearson Educotion

Solimun. 2002, Multivariate Analisis Structural Eguation Modeling (SEM). Universitas Negri Malang, Malang.

Sugiyono, 2014.Metodologi Penelitian Manajemen:Pendekatan Kuantitatif, Kualitatif, Kombinasi, Penelitian Tindakan Dan Penelitian Evaluasi, Cetakan Ke-3, Alfabeta, Bandung.

Swastha, Basu. (2009). Asaz-Asaz Marketing. Edisi Ketiga. Cetakan Ketujuh. Penerbit:Liberty. Yogyakarta

Nurfakhrusy, Fadhli. (2017). Pengaruh Periklanan, Promosi Penjualan Dan Penjualan Personal Pada Keputusan Pembelian. Skripsi. Universitas Lampung.

Umar (2010) Intrumen Penilitian Dan Pegumpulan Data. Metode Penilitian. Jakarta Universitas Indonesia. 